\title{
EMBODIED CULTURAL MEMORIES OF THE PUNJAB \\ GIDDHA DANCE AND SONG IN MIGRANT LONDON SPACES
}

\author{
ANN R. DAVID
}

Using detailed ethnographic fieldwork carried out in the area of Southall in west London, UK, this article examines the performance of the Punjabi folk dance of giddha in its community settings as well as its staged appearance in folk dance competitions. I argue for the power of performance to create and sustain cultural continuity in migrant settings, focusing on Southall where specific Punjabi histories, memories and identities are yoked together in several generations of diasporic existence.

Keywords: Dance, song, Punjabi, giddha, diaspora
$Z$ metodo natančnega etnografskega terenskega dela je raziskano uprizarjanje pandžabskega ljudskega plesa giddha tako $v$ skupnosti kakor tudi $v$ odrski postavitvi na revijah ljudskih plesov v Southallu v zahodnem delu Londona. Poudarjena je moč uprizoritev, da ustvarjajo in ohranjajo kulturo, osredinjeno na Southall, kjer so zgodovina, spomini in identitete, specifični za pandžabsko skupnost, združeni $v$ već generacijah diaspore.

Ključne besede: ples, pesem, Pandžab, giddha, diaspora

\section{INTRODUCTION}

This article examines the folk dance of giddha, a women's dance from rural Punjab in northwest India, in its reconstituted form in present-day west London in the suburb of Southall at an annual outdoor festival. Analysis of data gathered from ethnographic fieldwork, carried out as part of a UK Arts and Humanities Research Council grant (2011-13) on the cultural histories of the Punjabi-dominated environs of Southall, ${ }^{1}$ reveals a renewed interest by the women of Southall in the performance of this dance in new, local settings. The article argues how collective cultural memories of village life in the Punjab are produced, performed and reconfigured in the migrant, diasporic groups through the oral and performative traditions of dance and song at the annual women-centred Teeyan da Mela festival in Southall. ${ }^{2}$ The festival allows an insight into women's cultural, social and religious embodied memories, both individual and collective, performatively expressed through their dancing bodies and voices. Certain ridiculing of oppressive gender role expectations of patriarchal control and female compliancy, teasing about marriage difficulties and relationships, and the mocking

1 This 3-year AHRC project, 'The Southall Story' aimed to investigate the significant contribution made by the combination of political activism and cultural developments of the diasporic communities within Southall to the cultural life of Britain as a whole.

2 The women at the festival I attended were a mix of those settled in the UK for over 30 years, to more recent arrivals from the Punjab. 
of social niceties are possible in the safe space of the Teeyan da Mela. ${ }^{3}$ The festival provides a liminal and resistant arena where conformity and acceptance of the normative cultural systems can be challenged, and women can sing of past experiences of their homeland or of migrant experiences in the outskirts of London, albeit somewhat disguised in more playful expressions.

This 3-year research project documented over 150 interviews in Southall with key arts practitioners (in music, film, dance and poetry), and social activists, which forms the basis of the research material. It utilised an interdisciplinary framework of performance studies and ethnography. In particular, I worked with several bhangra dance groups, filming, dancing and talking with them, and spent extensive time observing, filming and in conversation with local Punjabi women, especially at the festival events. ${ }^{4}$ Data from research is now being analysed and the work presented here is the first iteration of a significant and under-documented area of Punjabi women's cultural practices in the UK.

The article additionally addresses the fact that the partition of Punjab in 1947 entirely changed the cultural and religious landscape of the region, and the horrific experiences of many Punjabis at this time were often not publicly voiced, nor retold by parents to younger generations. The silencing of such memories and cultural practices, as well as the later postcolonial and racial tensions in Southall in 1979, such as the murder of teacher Blair Peach, ${ }^{5}$ foregrounds the importance of the traditional customs and dance practices like giddha. Ethnomusicologist Gibb Schreffler writes how after partition of the Punjab, "folkloric dances have been valued as vehicles to showcase the state's identity" (Schreffler 2012: 127) and notes how every Punjabi cultural programme had to show the famous bhangra dance. ${ }^{6}$ Other regional folk dances, such as giddha, saami and kikli that were part of bhangra dance, were not co-opted by the new Pakistani state, nor the Indian government as part of national culture. Thus particular Indian nationalist ideologies were the driver

3 Purewal and Kalra's work (2010: 386) in the Punjab noted that "Teej in Punjab is more often found in the modernized context of girls' schools and women colleges."

4 This follows on from research work with other Hindu groups in the UK (Tamil and Gujarati) over a period of nearly 20 years.

5 Throughout the 1970s, an increase in numbers of Asians in Southall and their greater visibility led to even more instances of racism and violence from some members of the white community. This led to one of the defining moments in Southall's history, which was the uprisings in April 1979 and that resulted in the death of a white school-teacher, Blair Peach. A right-wing extremist and racist organisation, the National Front or the NF, held a political meeting in Southall Town Hall on 23rd April 1979. It was a deliberate act of provocation and attack on the non-white communities and led to terrible violence and bloodshed.

6 Bhangra dance is originally a men's harvest dance from rural Punjab, that has seen various manifestations since the time of Partition in 1947 - a reinvented national staged folk dance (1950s), a hybrid urban pop form (1980s Britain) and international competitive dance (1990s-2015). It is known for its high energy, syncopated rhythmic beat and lively presentation. Many new terminologies have emerged: bhangrapop, British bhangra, Bollywood bhangra, modern bhangra, to name a few. 
for the conscious selection of some cultural practices for a wider audience, whilst others, such as the giddha dance remained solely in community settings, or even disappeared.

Organised by one of the local community radio stations, Desi Radio, ${ }^{7}$ a registered charity founded in 1997 and granted a broadcasting license in 2002, the festival event celebrates womanhood. Teeyan, Punjabi for the north Indian festival of Teej that celebrates prosperity and happiness, and the beginning of the rainy season, occurs in the summer month of Sawan (July/August) and was, in the past, a time when married women returned home from their married locations to their natal villages for a brief period. The practice of virilocality, or the social system where married couples live with the husband's parents, meant at marriage, the wife would leave her natal home and was only able to return for childbirth, or as happens in many parts of rural India, for a few weeks at the beginning of the monsoon season. Now with the availability of mobile phones, and Internet communications, these practices are no longer so significant.

For the last 15 years in Southall, on four Sundays in July and August, the Southall south Asian women have gathered together to celebrate the Teeyan da Mela. Held at the local Dominion Centre for several years, it is now held in the playing field of a local school because of the increased numbers of women participating (approx. 500-600). It is interesting to note that in urban London, away from larger social networks in the Punjab, the presence of the community centre and its activities has potentially replaced the part played by the support system of the natal village, becoming central to many migrants' lives (Puwar 2012: 134). In this article, I explore the power of performance as an effective tool in maintaining cultural continuity, and cultural memory, drawing on material from cultural memory studies, as well as dance analysis and ethnographic discussion (David 2013). I analyse the complex strands coupled together in migrant settings of gendered expectations of social behaviour (identified below) alongside postcolonial issues of segregation, racial tensions and painful historical memories. At the Teeyan da Mela, history, memory and identity are yoked together where the past - village song and dance practices - can be replayed and yet are simultaneously reconstructed. Unpicking the "performative nature of remembrance" (Winter 2010: 20) in this festival, we find new embodied expressions of cultural continuity, as this article will argue, and a nostalgic, affective and yet transgressive take on diasporic life in London suburbs. How is social and cultural history being reconstructed by the performances of the past? And how does that nostalgic, rural imaginary (the past) get replayed in urban London (the present)?

In the local festival events, rhyming narrative couplets recited while performing dance movements tell stories of marital difficulties as well as presenting suggestive sexual innuendo in preparation for marriage. In these safe spaces where only women are present,

7 Desi Radio broadcasts 24 hours a day on Sky channels in the UK and Europe, and via the Internet, and is run by volunteers. Its aims, stated on the website <www.desiradio.org.uk $>$ are to work "to promote the Punjabi language, culture and the integration of the Punjabi community in the UK". 
giddha dance and the sung narrative texts, with explicit hand gestures, allow a permissive, artistic form for women to unburden themselves of migrant city pressures (lack of family networks, long, unsocial hours of working, unfamiliarity with cultural and social norms, etc.), and the social and cultural problems they experience. Codified behaviours of honour and dishonour do not allow for divorce when marriages break down, or the speaking of marital tensions or of pressures to produce children, and specifically male heirs. Female bodies are controlled, have to be discretely covered, and are expected to be compliant and subservient. The social or collective memory actively enacted here at the festival exposes the construction and maintenance of rural affiliations, coloured with a nostalgic discourse, despite relatively settled urban identities. ${ }^{8}$ This collective memory is at the same time, mediated by the women, as they sing of the past whilst interweaving the narratives of their present-day lives; perhaps a form of ethnographer Margaret Drewal's (1992) "repetition with revision" that she describes in her work with the Yoruba people of southwestern Nigeria.

The Southall women's improvised, witty words speak of old village narratives, such as "When her brother came to visit, her mother -in-law wouldn't let him in, so he came over the flat roofs," learned from grandmothers in formative years, mixed with stories of current issues that impact on migrant lives, as I go on to describe. Thus as historian Wulf Kansteiner notes, social or collective memory "can take hold of historically and remote events but it often privileges the interests of the contemporary" (Kansteiner 2002: 180).

Furthermore, the article considers the way giddha is now being co-opted by national and global youth culture in the form of stage competitions. The practice of competitive Indian folk dance is a major factor in diasporic youth university teams, in the UK, the USA and Canada. I draw on interviews with young people in Southall who are part of these performance teams, and note the contradictions and tensions associated with the female dancing body that they raise in their discussions. Here in these competitions, using the giddha dances, a notion of traditional performance is created and reified, displaying, as dance scholar Anthony Shay (2002: 9) notes, the "fun in the village" moves. The article examines this trajectory and notes parallels with competitive performances of Gujarati garba and raas as I discuss in an earlier book chapter (David 2014). Particular aspects of folklore are selected and privileged, using colourful costumes and spectacular choreographies, creating certain ideologies and specific versions of history. This constructed past reifies the rural the work in the fields, the sorting of the grain, the dancing in the village - in somewhat reductive and stereotypical performance events. The tensions between this staged, heavily optimistic display and the reality of women's lives and their performances of giddha, both at home and in the diaspora are noted.

8 Although not specifically relevant to the Southall women, it is worth mentioning that the famous Glassy Junction pub in Southall (now closed down) had two clocks on the wall - one showing the time in the Punjab, and the other, current UK time. The clocks, the photos of village life, and the displayed agricultural tools "play upon and visualize a nostalgic discourse, historically produced by immigrants /.../ fascinated with the trope of the village" (Axel 2001: 185). 


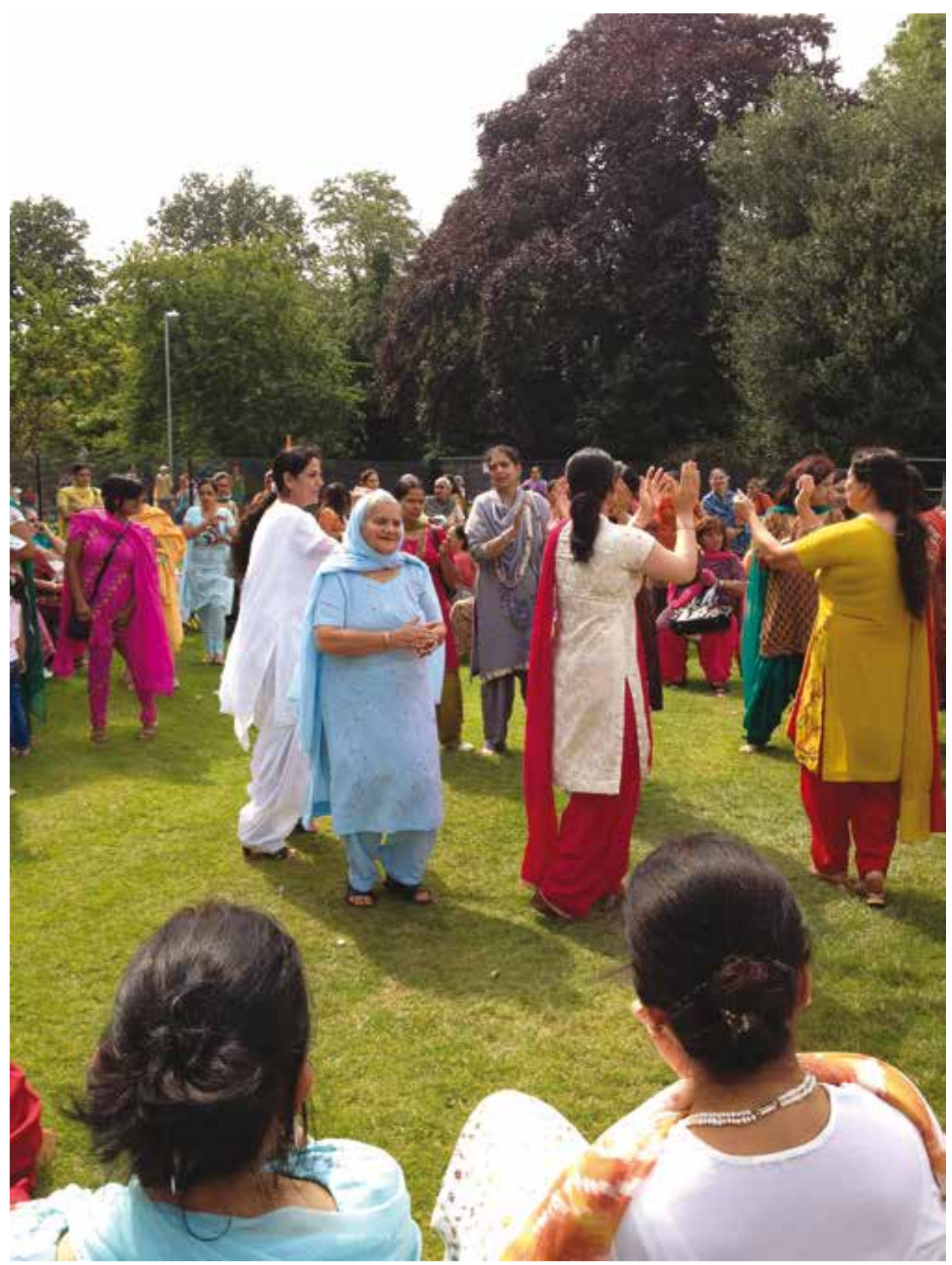

Women of different generations dancing giddha at the Teeyan da Mela festival in Southall, August 2012. Photo: Ann R David, 2012. 


\section{FORMS OF MEMORY}

The term "collective memory" (mémoire collective) has been used since the 1920s when it was introduced by French sociologist Maurice Halbwachs (1992/1925) in his work on memory discourse, although others, like cultural theorist Susan Sontag (2003) and historian Reinhart Koselleck (1989) have argued that all memory is in fact individual. A society (and groups and institutions) as an entity undoubtedly cannot remember, yet individual memories are fused and shared together through language and performative acts where they are "corroborated, confirmed, corrected, disputed /.../ and written down" (Assman 2010: 36). To avoid the conceptual problems with the concept of collective memory, scholars have used alternative terminologies such as "historical consciousness" (Funkenstein 1989: 5) or "collective remembrance" (Bottici 2010: 336), and the more common "folk memory" to emphasise the social framing of these memories and their active and agentive nature.

Literature scholar Aleida Assman suggests that it is helpful to separate the various strands forming a notion of collective memory (as different from individual memory), positing three categories of social memory, political memory and cultural memory (2010: 41-43). ' Social remembering is inter-generational and "refers to the past as experienced and communicated (or repressed) within a given society" (ibid: 41). It is a memory bank that can be seen to change after periods of about 30 years as younger generations create and perform new iterations of the past, such as can be found in the example of giddha dance. Political memory, on the other hand, is communicated from generation to generation through performative acts (commemoration rituals, public ceremonies, etc.) and collective participation that is mediated and to a certain extent (more in some ideologies) controlled (see also Bottici's "politics of remembrance" 2010: 335). This is partly applicable to the revived phenomenon of giddha dance, but is not directly relevant to the argument of this article, so is not discussed in detail here. Assman argues, in a similar vein to Diana Taylor's work (2003) in performance studies, that a third feature of cultural memory is an archive - in a preserved form - and an active "canon" that is performative and is continually being rebuilt and reformed. Cultural memory relies on what a members of a society have consciously selected for preservation and "shared remembering" (Assman 2010: 43) and its processes transform what is ephemeral into something considered more enduring. Taylor's work (2003) on the archive and, as she terms it, the repertoire, where she distinguishes between official, written historical records (the archive), and the embodied memory enacted (the repertoire) is pertinent to the discussion. Performance studies theorist Colin Counsell, commenting on Taylor's work, notes how "the repertoire is the domain of cultural process, and therefore the arena in which acts of resistance can take place" (Counsell 2009: 8). In the relatively safe domain of the women's only giddha celebrations, resistance to restrictive cultural codes and behaviours is certainly produced and enacted.

9 I note too that political philosopher Chiara Bottici in a different analysis breaks down the concept of collective remembrance into 3 levels - institutional, public and pedagogical (Bottici 2010: 343). 
The idea of history as performed and performative has gained credence over the last 10-15 years, with a surge of scholarly interest from history and performance scholars who have worked together on the performance of the past (see edited editions by Dean, Meerzon and Prince 2015; Counsell and Mock 2009; Tilmans, van Vree and Winter 2010), although scholars such as Hobsbawm and Ranger (1983) in their work on invented traditions preceded this. The idea of the "performative moment" and that "memory performed is at the heart of collective identity" (Winter 2010:11) is played out figuratively and literally, as we see in the case of the Southall women. Historian Jay Winter goes on to state that "the performance of memory is a set of acts, some embodied in speech, others in movement and gestures, others in art, others still in bodily form" (ibid.: 12), and verified as I argue, in the giddha practices. This where the repertoire may be privileged over the archive, to use Taylor's terminology, where the power of performance through emotion is affective and surpasses the usually more highly valued written text. The recent interest in performance as a trope of history has been additionally supported by significant growth in the field of memory studies, particularly the relationship between memory and culture (see Erll and Nunning 2008) and in anthropology (see Korom 2013).

\section{TEEYAN DA MELA}

Gathered together on a very warm Sunday in August 2012, on a playing field at the back of a local school in Southall, about 600 Indian (mainly Punjabi) women of all ages, are sitting, chatting, singing, dancing and socializing. Some are with young children, and everyone is dressed for the occasion in their best shalwar kameez ${ }^{10}$ suits and new jewellery. It is a relatively public space, ${ }^{11}$ but the event is private - I am the only Westerner there and one of the few non-Punjabis. The only men present are two young Punjabi male volunteers who have brought snacks and soft drinks that they serve to the women. Later in the afternoon, there is a visit by the local (male) Mayor, who is Muslim and speaks Punjabi.

The dancing erupts spontaneously. Women who have been sitting talking together begin, one by one, to come into the centre and to sing. It starts with smaller numbers gathered in one large circle and then, as the afternoon progresses and more women arrive, breaking up into many smaller circular groups. Musical accompaniment is simply clapping and singing, performed by the women watching in the outer circles and by those inside the

10 These are traditional outfits worn in South Asia consisting of long baggy trousers and a long, loosefitting top.

11 See also Nick Van Hear's analysis (2015) of diasporic engagement which he divides into three spheres: a) the private sphere consisting of the household and extended family; b) the more public sphere which he calls the "known community" - the associations, neighbourhoods, etc. that people belong to; and c) the "imagined community" that is largely public. This community event in Southall, I suggest, falls into the "known community" sphere, which is relatively public. 
formation who are dancing in a circular configuration counter-clockwise. Laughing and joking accompanies much of the performances. Loud claps, with the palms, sound on the beat, and later on the half beat and the quarter beat, and coordinate with the footsteps. These foot movements are minimal, with a particular use of the hip, as the foot is thrust out in front on each second beat, almost performing a rocking movement. The dynamic emphasis is into the ground, and the rhythm is a one-two, one-two repetition. Sometimes the hip movement is heavily accented and made very visible. Bodies bend forward to clap down, and move up again as the claps go up, in front of the chest and higher. The tempo often begins slowly, and increases rapidly. Gestures are made with one hand in the air, as the other hand holds the side of the shalwar dress and occasionally there are turns on the spot as the women move inside around the circle. These gestures accompany the songs, and relate to the words being sung and might include miming eating or drinking, pointing to bangles or anklets, showing frustration with hands outstretched in front. They are frequently quite sexually suggestive.

As important as the dance steps are the improvised rhyming couplets, sung as a call and response, and called boliyan ${ }^{12}$ or boli, an umbrella term for sung couplets, most often used in giddha folk dance forms. The verse couplets draw on the highly valued and popular Punjabi folk culture that is rich in traditional oral poetry. Usually a boli is sung and introduced by one woman, and the rest reply like a chorus. Some of the women will sing, and others then take over, in a very free and easy refrain. It is like a danced conversation, as one moves and sings, followed by others who respond in song and dance. The improvised songs are interspersed with established refrains related to weddings and pre-wedding rituals, such as take place at a Sangeet evening before a marriage, where songs are directed at instructing the bride-to-be about her wedding night. Certain stories and rhymes have run for generations and it is obvious that everyone present knows them by heart, having heard them throughout their formative years at social celebrations and women's events. But the spontaneous nature of much of the boliyan means that many have been composed especially for Southall, the area where they live, as the later analysis indicates. Songs can be bawdy, contain sexual innuendo and swear words, offering a more subversive slant on life and transgressing normative social behaviours for the women.

Social scientists Navtej Purewal and Virinder Kalra note that the festival of Teeyan da Mela in general "offers an insight into how women's popular rituals and practice can be reinterpreted within a collective notion of celebration and festivity" (Purewal amd Kalra 2010: 385). There is certainly evidence of such matters present at Southall's Teeyan da Mela. But concurrently, these events can be charged both with local meaning, or relate to the wider female Punjabi body, where narratives of selfhood articulate powerful ideas

12 The boli relating to weddings cover a huge range, for example suhaag - songs sung by the bride's family; khorhiyah - songs by the groom's family; tappeh - songs between a group of boys and girls; songs for engagement events - kurmai and chunni; the bringing of gifts to the bride nanakishak, and so on. See www.BoliyanBook.com 


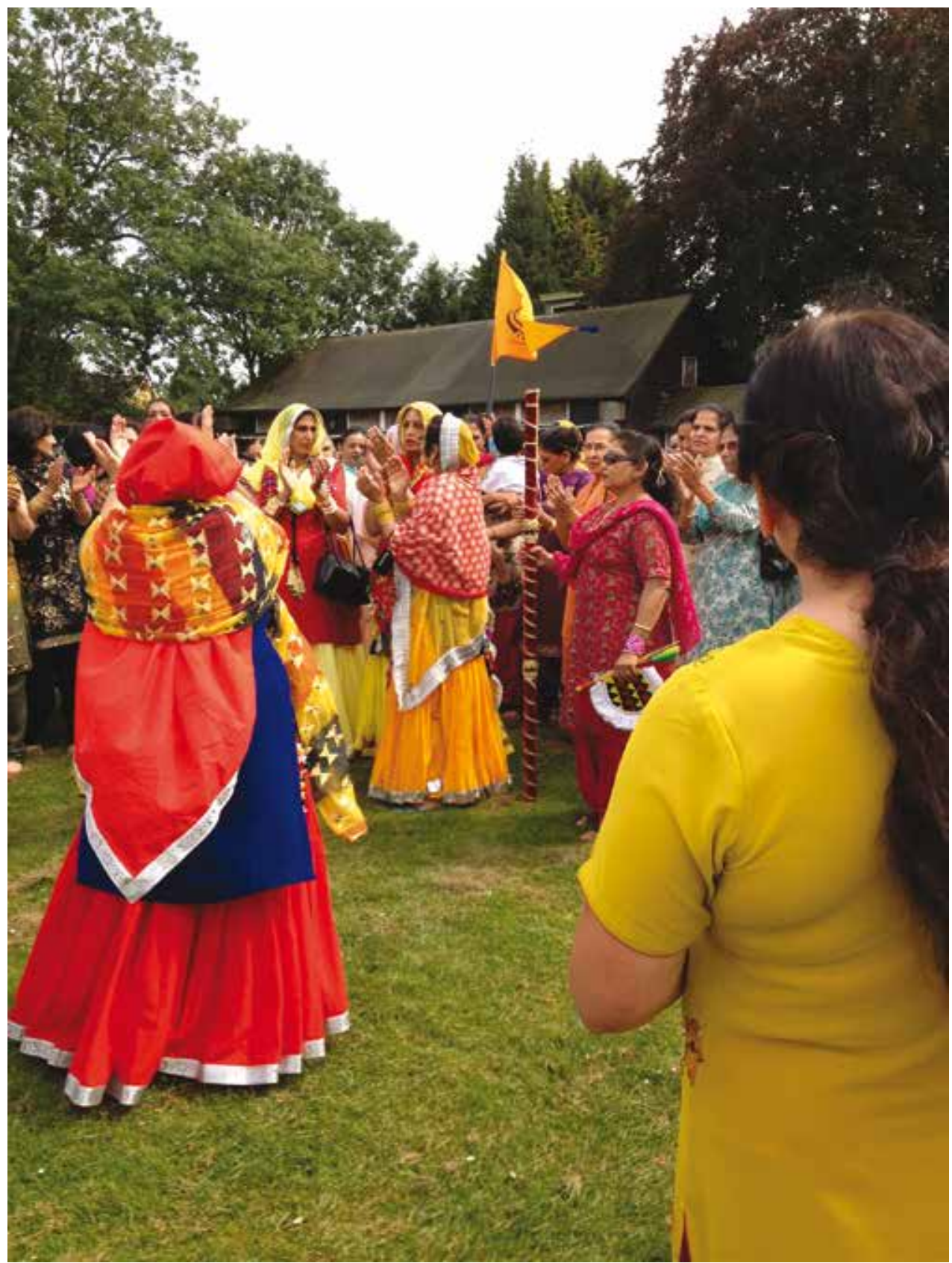

Dancing giddha in Southall, August 2012. Photo: Ann R. David, 2012. 
of honour (and dishonour), marriage, tradition and culturally expected behaviours. This summer women's festival is essentially Punjabi, a performance of nostalgia and identity where history and memory overlap. The Desi Radio organisers view the event as offering an emotional release for the women from the pressures of their lives, as well as the fun and shared enjoyment that is clearly experienced. Purewal and Kalra emphasize this when they state that "it does seem that these spaces act as safety valves rather than as vehicles for subversion" (ibid.: 386).

\section{BOLIYAN VERSES}

The boliyan verses sung at the Southall festival are, as noted, a mix of the old and the new, and are full of wit, rhymes and riddles. Themes of politics, love, sex, rejection, family feuds, complaints about husbands and mother in laws, and jealousies find their place in the songs. They also incorporate elements of fun, playful bantering and spirited humour. The following examples are a selection from a few of the songs performed at the Teeyan festival that I attended in 2012, translated from the Punjabi by Amarjit Khera of Desi Radio (Khera 2014). "When I'm here he treats me badly, but when I'm gone home to my mother's place, he's missing me" sings one of the women. Another describes a fictional Romeo-type character, called Dhola, who is "as sweet as sugar. Your lover should be like him" she teases as she sings and dances. The verse continues, "A tailor came to take my measurements," conveying a sense of outrage at the implication of sexual touching during a clothes fitting.

Much of the singing pokes fun at aspects of their lives, particularly their marital relationships. An old song that tells a husband "If you swear at my mother, I will sue you," now gets changed to "If you swear at my mother, I will call the London police". Some sing of requests for silver anklets from their husbands: "Why don't you buy me some, and I will make music when I dance?" Many of the songs focus on the importance of the dance, with refrains that call, "Come dance, come do giddha, let's do the giddha" and another saying, "Women from the Punjab are tall and very beautiful; when they dance, the earth will move". Other boliyan address the drunken state of the women's husbands, telling them, "Get lost, don't drink again." Their lyrics pour scorn on a new local Council member, who when elected in Southall, said she would buy the women new outfits to celebrate. "But when she saw the bill, her heart stopped", they sing, and gesture to the long, stretched out bill and touch their hearts. Other boliyan note that "Southall is like the Punjab now - you must listen to Desi Radio", incorporating in their rhymes the local sponsors of the festival. Some women sing controversially of the attack on the Sikh Golden Temple, in Amritsar, India in 1984. The event always ends with a fake marriage procession, enacted by the women, and the "main target for the mockery is the groom and his family" (Purewal and Kalra 2010: 386). "We don't like you so she's not going to go with you" they sing, to the (acting) groom's party, whilst knowing that she has to leave with them. The boliyan songs of the 


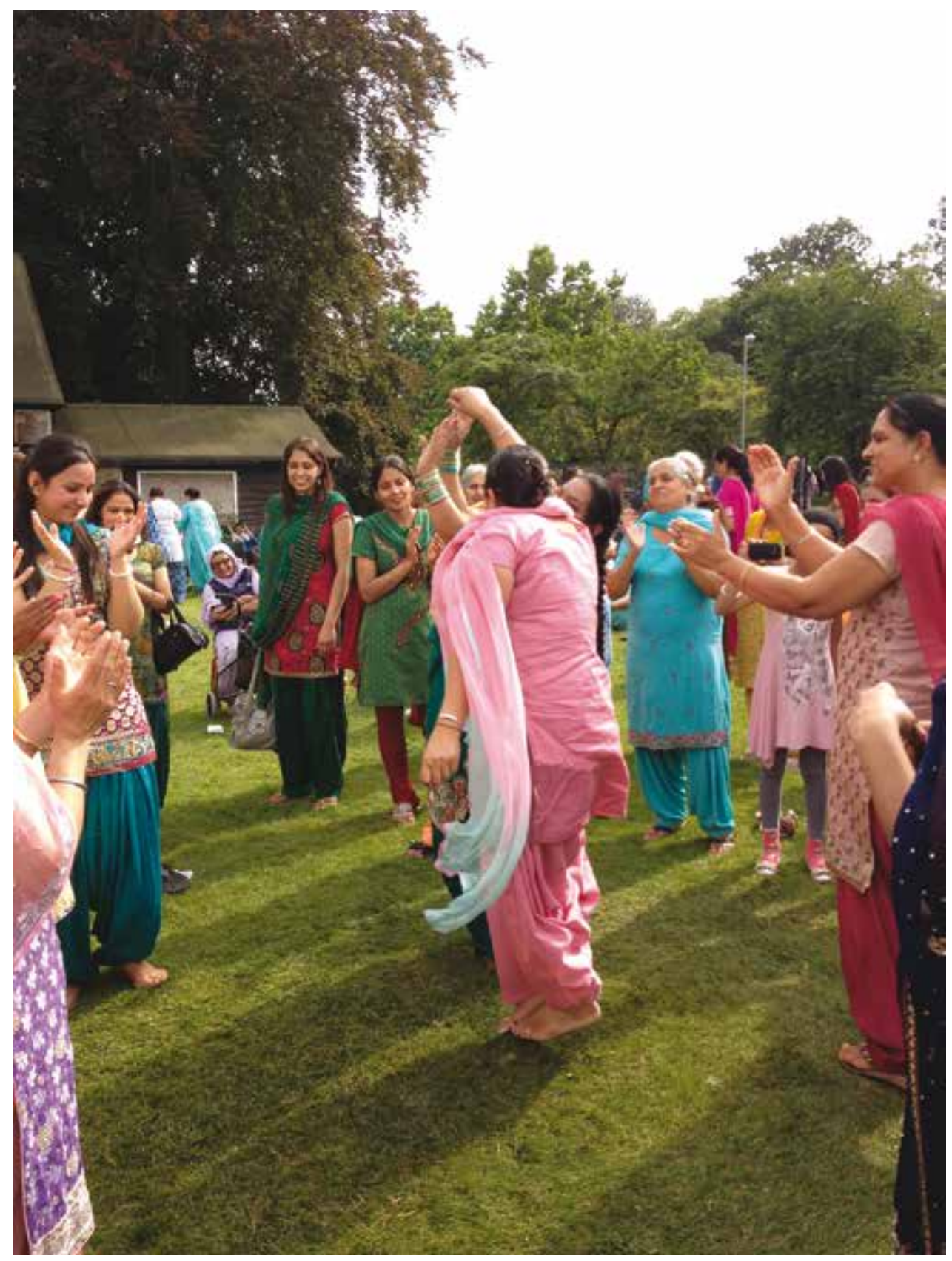

Dancing giddha in Southall, August 2012. Photo: Ann R. David, 2012. 
Teeyan da Mela not only maintain a significant continuity for the Punjabi language but also act as a record of migrant life experiences in their references to the local UK police, to specific Southallian characters, to aspects of living in Southall, and of significant political events, as noted above.

According to one of the elders, eight years ago when the festival event took place in the local community centre, two Punjabi women approached the organizer with a strange question, "Can we sing dirty boliyan?" Rather bemused, she agreed, and they sang and danced, telling a poignant story of a visit to the gurdwara. ${ }^{13}$ Unable to get pregnant, one of the women had gone for advice from one of the religious leaders. After talking, the man asked her to massage his feet, and then kept telling her "Go higher, go higher," till she had to touch him inappropriately. He then tried to rape her. The only way she could speak of this terrible event was to sing about it, as a kind of catharsis, feeling unable to voice such matters in the community, due to powerful cultural behaviour codes relating to honour and dishonour. ${ }^{14}$

Philosopher Guy A. Widdershoven aptly notes that "life and story are not two separate phenomena. They are part of the same fabric, in that life informs and is formed by stories" (Widdershoven 1993: 2). Narratives are at the very heart of a human being's need to communicate and to make sense of the world, and the sharing of memories, even difficult ones, is a prime social activity. In this way, using narrative, performative action and music, as in the case cited above, the trauma might be usefully distanced, or accepted, or even potentially healed (see also Obeyesekere's 1990 work on the analysis of cathartic rituals). Studies on the effect of music and song on the chemistry of the brain have shown that that the regions in the brain affected are those directly involved in emotions, leading to a sense of restoration. Likewise many studies have proven that music facilitates biological changes in the heart rate, respiration and affects the cerebral blood flow in the brain (Panksepp and Bernatzky 2002; Peretz and Zatorre 2005).

\section{EMBODIED MEANINGS AND MEMORIES}

A film made in 1990 by Punjabi elders in Southall titled Aaj Kaal ${ }^{15}$ [Today, Tomorrow, Yesterday] and directed by sociologist Avtar Brah showed the significance of the performance

13 Gurdwara is the name for the Sikh temple, or place of worship. It means 'gateway to the guru'.

14 These sorts of incidents narrated in the songs about cultural expectations and cultural taboos appear not to be so removed from the stories that fill newspapers today regarding the abuse of young men and women by religious leaders, or by significant media figures.

15 Aaj Kaal was made by the community elders attending the Milup Day Centre in Southall as part of an adult education project. Importantly it was as Puwar describes it, "produced in a careful and reflexive manner/.../ an exercise in participative pedagogy" in which the elders had control over all content and direction of the film, a new practice at that time (Puwar 2012: 126). 


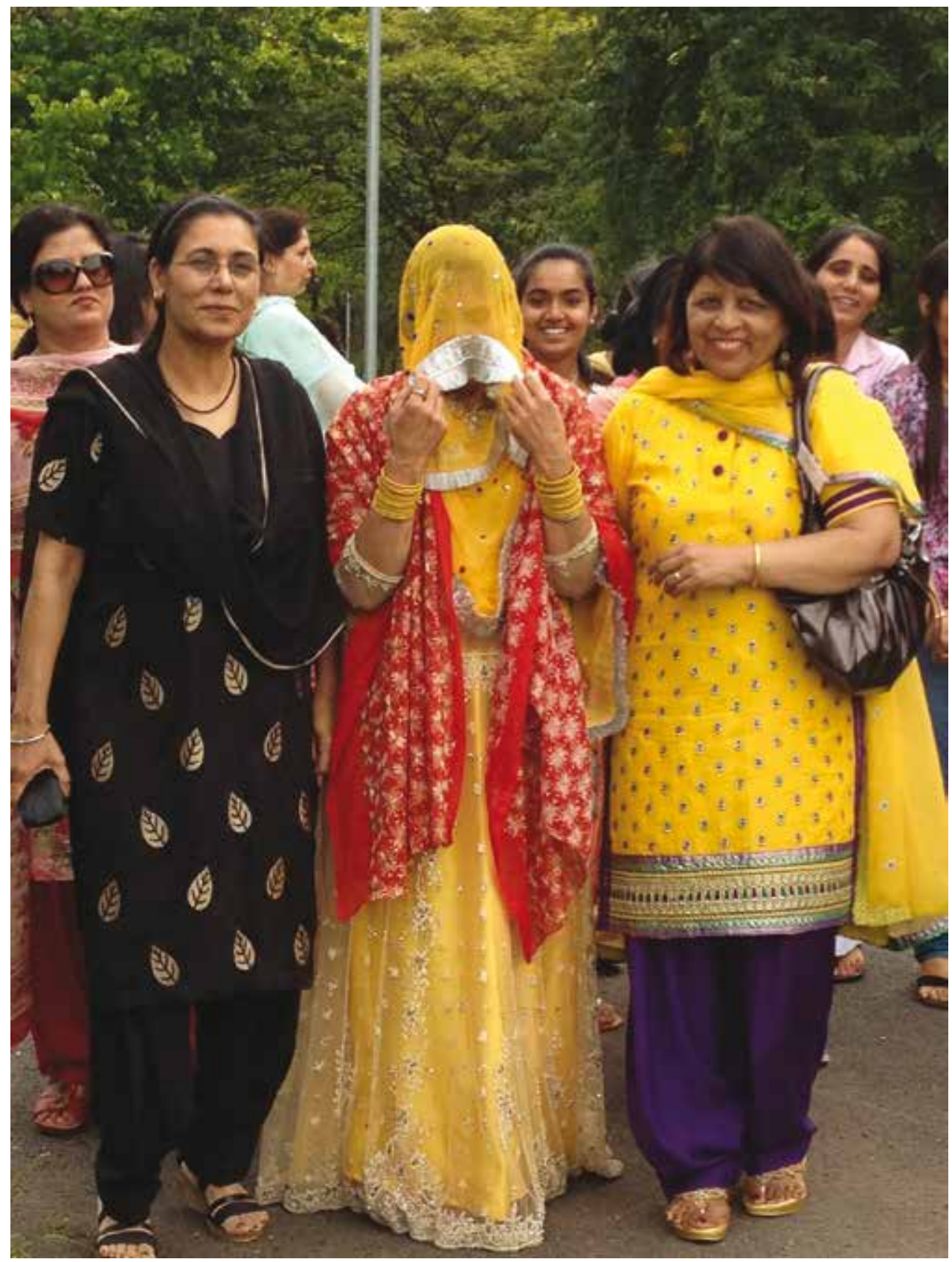

Fake marriage procession at the Teeyan da Mela in Southall, August 2012. Photo: Ann R. David, 2012. 
of giddha in the women's lives. Nirmal Puwar, writing later on the making of the film, notes how giddha has

enabled Punjabi women to air their joys, frustrations and sorrows. It is full of gendered mimicry and risqué words, and moves... that South Asian women have carried and reinvented across time and space in their diasporic journeys of migration. (Puwar 2012: 136)

Puwar adds that before the days of transnational travel and Internet communications, audiotapes of boliyan "were recorded at home among female relatives. These were usually sent as parcels among relatives when weddings and other special occasions could not be attended easily across continents" (ibid.), indicating the cultural significance of the boliyan verses. The film - encompassing discussions and tales of racism, caste, marriage, migrant journeys and historical events such as Partition - ended with a unprompted showing of giddha dance by the women elders, led by two of the film's main participants. Powerful stories, probably never before spoken on air and certainly not publically, tell of women's rape, and subsequent suicides during Partition, and the "gendered pain, shame and ostracisation of the women" (Puwar 2012: 133), as well as the recounting of the horrific, post-colonial race problems of Southall in the 1970s and 80s. The final dance scene, notwithstanding, provides a lively, fun and energetic culmination of the elders' mixed memories of their life experiences in the Punjab, in East Africa and in Britain, "in an admixture of pleasure, performance and gendered territory" remarks Puwar (ibid.: 137). Brah herself commented that the dancing shows a kind of female subjectivity that places the community centre as a location both to reminisce about the difficulties of their lives but also as a space of pleasure (www.case-stories.org/avtar-brah).

Evaluating the performances at the Teeyan da Mela festival, it is noticeable that the women are not simply passing on their cultural, or folk memory but are "enacting new visions of a collective past" (Counsell 2009: 6) where fresh meanings are formed and embodied, as they weave the themes relating to their lives in Southall into the more traditional songs. This is their way of negotiating and transforming the past into the present, a present that is entirely relevant to their current experiences. Kansteiner notes that collective memory is "as much a result of conscious manipulation as unconscious absorption, and it is always mediated" (Kansteiner 2002: 180), echoing Hobswawm and Ranger's analysis of the careful logic of the construction of the past, such as in the creation of nationalism (1983). Are we able to discern who "owns" such cultural memory? In the scenario I have described at the festival, the women are undoubtedly in control, and embody a freedom to compose and to sing the narratives of their lives, easing the pressures they experience contemporaneously. They are making meaning, constructing individual and yet conjoined memories of the past, but which are reaffirmed and reconfigured in the present. The women are negotiating their private experiences and memories with social expectations and the sense of the imagined global Punjabi body in the ways described above (cf. Anderson 1983). 


\section{COMPETITIVE FACTORS}

In a further contemporary trajectory of the dance form, giddha dance now appears alongside bhangra performance (and mixed with bhangra performance) at Indian weddings, in dance competitions and in Indian films. Here the dance is often positioned with bhangra as Schreffler notes, as "brother/sister" dances. Schreffler continues, "This follows the modern presentation of bhangra and giddha as male and female aspects of a Punjabi dance, before the relatively recent rediscovery of men's giddha"16 (Schreffler 2012: 132). Not only does Schreffler point out that giddha is not just a women's dance, challenging the perceived notions of its femininity, but his statements also reveal an articulation of bhangra charged with representing modernity and giddha with tradition, setting up, as anthropologist Nicola Mooney states a "gendered paradigm which associates women with tradition" (Schreffler 2008: 111). This perceived notion is seen in the attitudes of the younger generations, when they learn the dance for competitions.

One young woman, Hakiran Bhogal, who teaches friends at a London university, and in Southall, to dance giddha, articulated how she struggled to get the women in her team to view the dance as modern and "cool". "I find the girls don't understand what it is. They don't appreciate it and hence they don't want to do it, because it is associated with older women in the village" she said (Bhogal 2012). She worked with her all-female team and they won a major UK competition, the Bhangra Showdown ${ }^{17}$ in 2010. But, Bhogal explained "I made sure I wrote down the lyrics and explained the meaning of them. I told them about how they need to express the form of art when they are talking, and to use facial expressions. The whole point of the Bhangra Showdown is to be entertaining" (ibid). She verified how much of the dance and song is improvised, but also how many songs draw on the past:

Maybe a rhyme a riddle, [they] take the piss out of their husband because that's what they normally do; they tell you about their mother in law, their sister, and how so and so is pissing them off food. So it is quite entertaining. Then you dance at the same time, and you have different forms of these for different occasions too. (Bhogal 2012)

Giddha performances in competition, such as the dances Bhogal creates use accompanying music from live $d$ hol drummers with a medley of songs, set choreography, and the girls moving in formation - quite different to the social, community expression discussed

16 E.g. Malwai giddha performed by men.

17 Bhangra Showdown started in 2007 and was created by a team at Imperial College, University of London to emulate in the UK the dance competitions held in North America. Although the focus has been on bhangra, girls' teams are encouraged and many dance staged giddha. It has been running each year since then and has gained enormous popularity, with TV and music stars as special guests. The competition is between UK university dance teams. See http://thebhangrashowdown.co.uk/. 


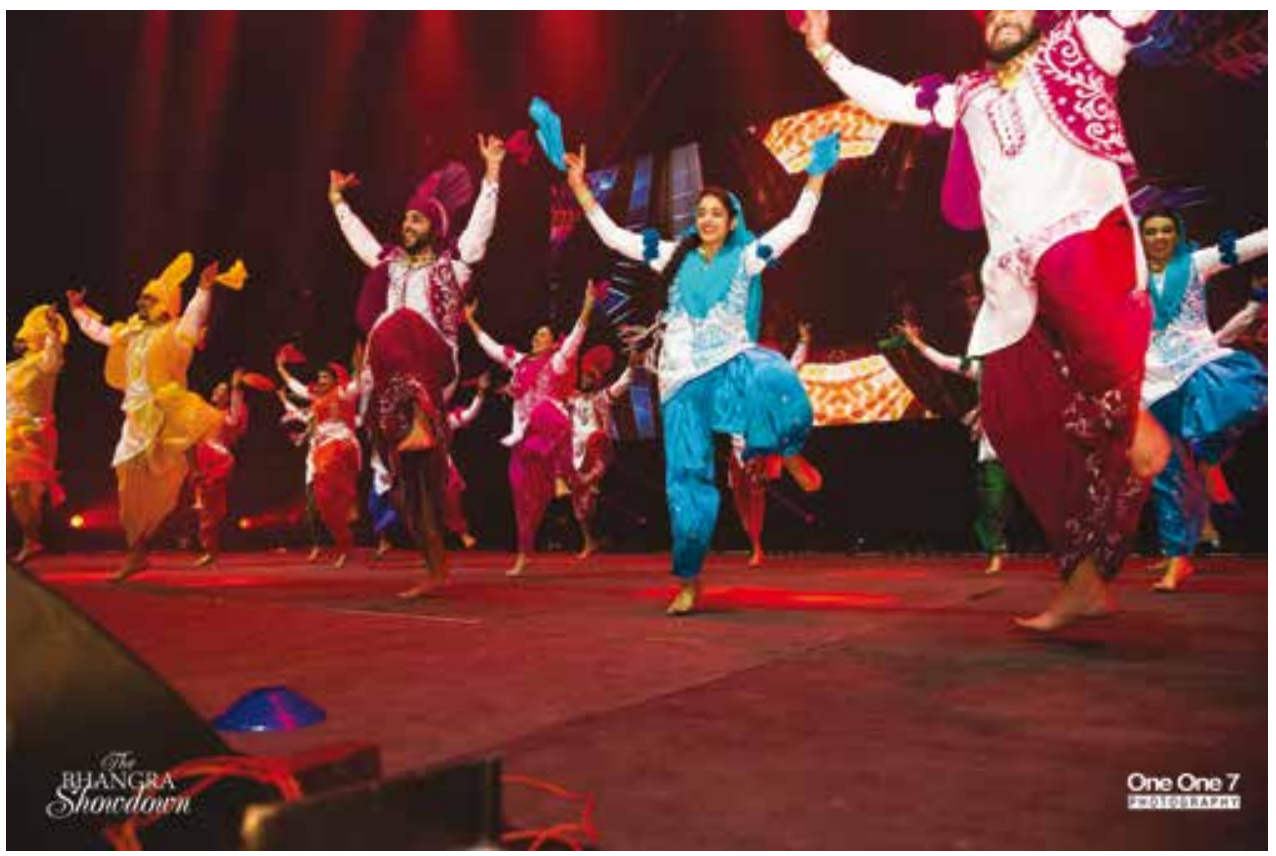

Bhangra Showdown 2015. Photo: One One 7 Photography.

earlier. One major change in staged performances for both bhangra and giddha is that the steps no longer follow the boliyan verses. Mani Singh, leader of a Southall bhangra group and judge at the UK bhangra competitions, explained that this is because the movements are created first, as they need to be "showy" and that audiences now do not understand Punjabi so well. He continued, "Everyone is looking to be entertained. That's what they want. They don't care, /.../ they don't pay that much attention to what the lyrics are" (Singh 2012). Both Singh and Bhogal place bhangra and giddha moves into their mediated choreographies, mixing the folk styles for their audiences. ${ }^{18}$

The selection of dance moves for entertainment and competition complicates notions of cultural traditions, authenticity of performance and ideas of homeland. Chacko and Menon noted that in bhangra college competitions in the US, the display and competitive performances by Indian students had become a type of idealisation or objectification of culture, where a notion of traditional performance is created and reified. Their fieldwork revealed "that 'traditionality' is one of the most significant formal judging criteria" (Chacko and Menon 2013: 105) in the competitions. Yet as is well known, especially within cultural practices such as dance and music, customs are constantly changing and developing. And

18 These changes to older styles of dances are seen elsewhere, such as in swing dancing. On one hand it is more and more choreographed and ornamented with ever more complex "solo jazz" sections; on the other it emphasises the "old-timers" spirit of improvisation on the social dance floor and therefore more of a lead-follow logic of performance. 
indeed it seems that judges in the UK also used such nostalgic criteria for marking, stating of a group that won, that "they did folk, very traditional, really really traditional. Very good. Exactly what we used to see in India" (Singh 2012). Bhogal, talking of her winning giddha set at the 2010 Bhangra Showdown at London's Hammersmith Apollo, emphasised the point about dancing in a traditional manner: "I made it fundamentally traditional because I knew that was what the judges were looking for" (Bhogal 2012). However, the heightened theatricalisation of the performances of both giddha and bhangra in staged competitions, as anthropologist David Guss points out, "abjures any mention of true historical conditions and replaces them with the stage creation of a mythic, detemporalized past" (Gus 2000: 14). ${ }^{19}$

Dance competitions worldwide perform a certain function in constructing and confirming the notion of a Punjabi Asian identity, especially for the young generations. In the Punjab, university dance teams are seen by young British Asians as "more folky, more traditional and much more competitive" (Singh 2012), and as very different from the British scene. "In India everyone knows the words and the music, and they know the beats ... there are points for best lyrics, for facial expression, size of turbans and for everyone jumping at the same time" (ibid.). In the UK, since 2008, dance groups have created national shows such as Bhangra Showdown (its equivalent in the USA is Bhangra Empire) that have rapidly increased in size and popularity over the last 5-6 years, so much so, that this UK competition now attracts teams from the USA and Canada who want to participate. In 2012, a famous US bhangra team was invited as a guest act, dramatically changing the focus of the competition from national to international. Other recent UK shows in 2012 include Bhangra Wars in Wolverhampton, Folk-Stars in Birmingham, and Bhangra Breakdown Show on BBC Asian Network. There are no competitions solely for giddha in the UK, unlike India, but most of the bhangra competitions mentioned above include giddha sets or mixed choreographies with giddha and bhangra moves. I doubt that giddha will ever take centre stage in these competitions, as it is still perceived as a women'sonly dance and as a marker of the past. Its simple footwork and hand claps do not offer the dynamism or high energy of the bhangra moves that excite the crowds watching the competitive staging of these dances. Perhaps it will be subsumed by its more popular and lively cousin, bhangra, in a similar trajectory that we see has happened with the Swing dance revival, where Lindy Hop has become the dominant form and other dances such as black bottom or cake walk have been forgotten.

19 This tension is common to dance revivals of the last decades, such as swing, tango and salsa. Claims of authenticity, of course, are always linked with the question of who has power to determine what is authentic and what is not (see Alcedo's work in Dankworth and David 2014). 


\section{CONTESTED NOTIONS OF THE FEMALE BODY IN GIDDHA PERFORMANCE}

The giddha performances in women's only spaces, such as at the festival in Southall, or in women's colleges and single-sex schools in India appear relatively unproblematic in relation to common cultural concerns about the female body on display. As the dancing takes place in safe, gendered spaces, such as those mentioned or at Sangeet nights in homes before a wedding, there is a confidence to dance freely. But this was not always the case. Amarjit Khera, at Desi Radio speaks of how the Southall Teeyan festival was stopped after the 1984 attack on the Golden Temple due to community fears of reprisals in the area (Khera 2014). In addition, singer Mohinder Bhamra, interviewed for the Southall Story project, told of how in the late 60 s and early 70 s, most women were shy of dancing in public:

We used to go the Midlands [Punjabi community] to perform. Midlands at that time was so backward, because it was all village people, most of them settled in Midlands. And many used to enjoy the weddings. I used to sing from the stage and I was feeling that I'm the only lady here. I said listen to me, "I'm not going to sing, bring all the ladies here." So they started dancing, slowly, slowly, they were so shy. But nowadays, you find more ladies are dancing than men [laughs]. (Bhamra 2011)

Her granddaughter, Rupi, now in the Vasda Punjab performance group in Southall, where she dances both giddha and bhangra, takes up the story, telling how her grandmother did not want her to perform at weddings, as "it was not seen as a good thing," a firmly held view by this older generation. She accepts it now, but only because Rupi is dressed properly (as she views it) in traditional clothing and with a dupatta (scarf) on her head. Yet the open display of the female dancing body and its inherent cultural tensions are still present in the younger generations, as Bhogal argues here, when she speaks of how men do not want the girls to dance publicly.

A lot of Punjabi men I have met so far when I mention the whole dancing thing they don't really like it. Even with guy mates, I feel there is a certain part of them thinking, "I don't want her to carry on with that" /.../ A lot of girls won't do it because their boyfriends have said to stop, but they have a lot of potential. It's definitely double standards; men can go out, drink, wear what they want and go out with the girls they want to, but for girls it is a completely different story and you see that in the dance too. There is a massive stereotype about dancing and how it is not good. (Bhogal 2012) 
This raises the question of what the younger generations do with the received memories of the primary generations of migrants. Despite urban modernities, and greater freedom in general, Punjabi women are still subject to social and cultural controls (unlike the men) and dancing remains a contested arena. Although many of the young people like Bhogal are performing at weddings and in competitions where university dance teams are the main players, most girls do not continue to dance after they finish university, or after they marry. The tensions around the female body on show only emphasise the importance of the community performances of giddha, where acts of resistance against patriarchal constraints, gender role expectations and female compliancy may be witnessed.

\section{CONCLUDING REMARKS}

This study of giddha dance performance in the UK reveals multiple potential readings, extensive varieties of meaning and several diverse sites of production. The themes of remembering and restoration through performance allow us to recognize, reflect on and understand the cultural expressions that form an essential part of human existence. I have argued that through the power of performance, cultural memories are enacted, allowing a level of cultural continuity to be maintained. Such memories, whilst being performed are also being created afresh as new configurations of old rhymes and stories are woven into modern day narratives, as we see in the example of the Southall women's boliyan verses. By incorporating aspects of Southall, their London migrant home, into the rural and more traditional rhymes of their native Punjab, the women are negotiating a way through their past and present lives, potentially interweaving the dual (rural home life and city migrant life) and conflicting parts into a manageable whole. Current pressures are relieved, readdressed, revisited and potentially repaired. Studies of cultural memory have shown how there is a link with the study of emotion, particularly in areas of trauma and nostalgia, as others such as historian Carrie Hamilton (2012), and anthropologist Gananath Obeyesekere (1981) have noted. Hamilton argues how "memory and emotion are also fundamentally concerned with the relationship between the personal and the political, the private and the public, the individual and collective" (Hamilton 2012: 63).

I have shown in this article the importance of the past in constructing what is new, and the role narrative plays in such making of memories. Hobsbawm and Ranger remind us that invented mythologising of the past occurs more frequently when "when there are sufficiently large and rapid changes" (Hobsbawm and Ranger 1983: 5) in societies, such as here in the Punjabi history of Partition and migration. Further questions arise and will need to be engaged with as the research is unravelled in more detail. What is consciously remembered and what is consciously forgotten in the curation of memories over generations? What frames of power are embedded the work of culture and dance? Are we seeing here a nostalgically framed narrative of loss? And what is it that is found in the new 
diasporic setting - is it hope, connections, growth and prosperity, or is it disillusion, and disenchantment? ${ }^{20}$

Above all, this research focus remains on the specific locality of Southall, whilst engaging in a global dialogue that acknowledges changing patterns of migration, diasporic identities and political nuances of practised customs. Southall's setting as a complex locale for migrant communities, who each bring their memories of traumas such as civil war, loss, migration and settlement along with the area's own racially tense history remains a rich and layered environment to encounter, participate in and to investigate. Giddha dance as a cultural practice and competitive dance form lives on, playing its significant part in the handing on of traditions and the creation of new ones, and offering different generations a performative power to transform the past into the present and perhaps, to the future.

\section{ACKNOWLEDGEMENTS}

Thanks are due to the AHRC for funding the initial project and to the lead investigator, Dr Jerri Daboo. I also acknowledge the help given by those at Desi radio, particularly Amarjit Khera and Pam Sidhu Thind, as well as dancers/choreographers Harkiran Bhogal and Manpreet Singh. Part of this article appears in the Conference proceedings of the $28^{\text {th }}$ Symposium ICTM Study Group on Ethnochoreology and earlier drafts were presented at the above symposium in Korčula, Croatia (2014) as well as at the Cultural Literacy in Europe conference in London (2015). Thanks are due to colleagues who offered feedback on these earlier drafts and on the current article.

\section{REFERENCES}

Alcedo, Patrick. 2014. How Black is Black?: The Indigenous Atis Compete at the Ati-atihan Festival. In: Linda E. Dankworth and Ann R. David (eds.), Dance Ethnography and Global Perspectives: Identity, Embodiment and Culture. Basingstoke: Palgrave MacMillan, 37-57.

Anderson, Benedict. 1983. Imagined Communities. London and New York: Verso.

Argenti, Nicolas and Katharina Schramm (eds.). 2010. Remembering Violence: Anthropological Perspectives on Intergenerational Transmission. New York and Oxford: Berghahn Books.

Axel, Brian Keith. 2001. The Nation's Tortured Body: Violence, Representation, and the Formation of a Sikh "Diaspora". Durham and London: Duke University Press.

Bhamra, Mohinder. 2011. Personal communication to Jerri Deboo, Southall.

20 Acknowledgements are due here to the presentations given at 'The Impact of Diasporas' event in London on September 17th 2015. The symposium marked the ending of a five-year interdisciplinary research programme funded by the Leverhulme Trust and run by the University of Leicester and Oxford Diaspora Programme. 
Bhogal, Harkiran. 2012. Personal communication to Rowan McLelland, London.

Bottici, Chiara. 2010. European Identity and the Polics of Remembrance. In: Karin Tilmans, Frank van Vree and Jay Winter (eds.), Performing the Past: Memory, History and Identity in Modern Europe. Amsterdam: Amsterdam University Press, 335-359.

Brah, Avtar. 2013. Interview on www.case-studies.org/avtar-brah (accessed 4. 9. 2015).

Chacko, Elizabeth and Rajiv Menon. 2013. Longings and Belongings: Indian American Youth Identity, Folk Dance Competitions and the Construction of 'Tradition'. Ethnic \& Racial Studies 36 (1): 97-116.

Counsell, Colin. 2009. Introduction. In: Colin Counsell and Roberta Mock (eds.), Performance, Embodiment and Cultural Memory. Newcastle-upon-Tyne: Cambridge Scholars Publishing, 1-15.

Counsell, Colin and Roberta Mock (eds.).2009. Performance, Embodiment and Cultural Memory. Newcastleupon-Tyne: Cambridge Scholars Publishing.

David, Ann R. 2013. Ways of Moving and Thinking: The Emplaced Body as a Tool for Ethnographic Research. In: Peter Harrop and Dunja Njaradi (eds.), Performance and Ethnography: Dance, Drama, Music. Newcastle upon Tyne: Cambridge Scholars, 45-66.

David, Ann R. 2014. Embodied Traditions: Gujarati (Dance) Practices of garba and raas in the UK Context. In: Linda E. Dankworth and Ann R. David (eds.), Dance Ethnographies and Global Perspectives. Basingstoke: Palgrave MacMillan, 13-36.

Dean, David, Yana Meerzon and Kathryn Prince (eds.). 2015. History, Memory, Performance. Basingstoke, UK: Palgrave MacMillan.

Drewal, Margaret T. 1992. Yoruba Ritual: Performers, Play, Agency. Bloomington: Indian University Press.

Erll, Astrid and Ansgar Nunning (eds.). 2008. Media and Cultural Memory: Cultural Memory Studies: An International and Interdisciplinary Handbook. Berlin and New York: Walter de Gruyter.

Funkenstein, Amos. 1989. Collective Memory and Historical Consciousness. History and Memory 1 (1): 5-26.

Guss, David. 2000. The Festive State: Race, Ethnicity, and Nationalism as Cultural Performance. Berkeley: University of California Press.

Halbwachs, Maurice. 1992 (1925). On Collective Memory. [Trans. L.A. Coser]. Chicago: University of Chicago Press.

Hamilton, Carrie. 2012. Cultural Memory and the Emotions: Exploring the Connections. In: Graham Dawson (ed.), Memory, Narrative and Histories: Critical Debates, New Trajectories. Brighton: University of Brighton, 63-71.

Hobsbawm, Eric and Terence Ranger (eds.) 1983. The Invention of Tradition. Cambridge: Cambridge University Press.

Kansteiner, Wulf. 2002. Finding Meaning in Memory: A Methodological Critique of Collective Memory Studies. History and Theory 41 (2): 179-197.

Khera, Amarjit. 2014. Personal communication to Ann R David, Southall.

Korom, Frank J. (ed.). 2013. The Anthropology of Performance: A Reader. Chichester: Wiley-Blackwell.

Koselleck, Reinhart. 1989. Social History and Conceptual History. International Journal of Politics, Culture and Society 2 (3): 308-325.

Mooney, Nicola. 2008. Aaja Nach Lai [Come Dance]: Performing and Practicing Identity among Punjabis in Canada. Ethnologies 30 (1): 103-124.

Obeyesekere, Gananath. 1981. Medusa's Hair: An Essay on Personal Symbols and Religious Experience. Chicago: University of Chicago Press. 
Obeyesekere, Gananath. 1990. The Work of Culture. Chicago: University of Chicago Press.

Panksepp, Jaak and Gunther Bernatzky. 2002. Emotional Sounds and the Brain: the Neuro-affective Foundations of Musical Appreciation. Behavioural Processes 60: 133-155.

Peretz, Isabelle and Robert J. Zatorre. 2005. Brain Organization for Music Processing. Annual Review of Psychology 56: 89-114.

Purewal Navtej and Virinder Kalra. 2010. Women's 'Popular' Practices as Critique: Vernacular Religion in Indian and Pakistani Punjab. Women's Studies International Forum 33:383-389.

Puwar, Nirmal. 2012. Mediations on Making Aaj Kaal. Feminist Review 100: 124-141.

Schreffler, Gibb. 2012. Desperately seeking Sammi: Re-inventing Women's Dance in the Punjab. Sikb Formations: Religion, Culture, Theory 8 (2): 127-146.

Shay, Anthony. 2002. Choreographic Politics: State Folk Dance Companies, Representation and Power. Middletown, CT: Wesleyan University Press.

Singh, Manpreet. 2012. Personal communication to Rowan McLelland, Southall.

Sontag, Susan. 2003. Regarding the Pain of Others. London: Hamish Hamilton.

Taylor, Diana. 2003. The Archive and the Repertoire: Performing Cultural Memory in the Americas. Durham and London: Duke University Press.

Tilmans, Karin, Frank van Vree and Jay Winter (eds.). 2010. Performing the Past: Memory, History and Identity in Modern Europe. Amsterdam: Amsterdam University Press.

Van Hear, Nick. 2015. Spheres of Diaspora Engagement in Conflict Settings. (Unpublished paper given at The Impact of Diasporas conference, London, 17.9. 2015).

Widdershoven, Guy A. 1993. Hermeneutic Perspectives on the Relationship between Narrative and Life History. In: Ruthellen H. Josselson and Amia Lieblich (eds.), The Narrative Study of Lives. London: Sage, $1-20$.

Winter, Jay. 2010. The Performance of the Past: Memory, History, Identity. In: Karin Tilmans, Frank van Vree and Jay Winter (eds.), Performing the Past: Memory, History and Identity in Modern Europe. Amsterdam: Amsterdam University Press, 11-23.

\section{UTELEŠENI KULTURNI SPOMINI PANDŽABA. PLES GIDDHA IN PESEM LONDONSKEGA IMIGRANTSKEGA PROSTORA}

Preucevanje plesnih izvedb plesa giddha $v$ Veliki Britaniji razkriva različna branja, odkriva večpomenskost in kaže na različna mesta ustvarjanja. Teme spominjanja in obnove v uprizoritvah nam omogočajo, da spoznamo, premislimo in razumemo kulturne izraze, ki tvorijo bistven del človeškega obstoja. Trdim, da je mogoče z izvajanjem plesa in pesmi, v katerih je zajet kulturni spomin, obraniti raven kulturne kontinuitete. Takšni uprizorjeni spomini so hkrati tudi poustvarjeni kot nove razvrstitve starih ritmov in zgodb, vpletenih $v$ sodobne pripovedi, kakor lahko $v$ Southallu vidimo na primeru ženskega petja verzov boliyan. $Z$ združevanjem vidikov Sauthalla, londonskega priseljenskega doma, ter ruralne in bolj tradicionalne pesnitve domačega Pandžaba ženske sklepajo vez med svojimi sedanjimi in preteklimi življenji, spletajo dvojnost (ruralnega domačega in mestnega migrantskega življenja) in nasprotujoče si dele v pomensko celoto. 
Trenutni pritiski so na novo premišljeni in labko celo predrugačeni. Študije kulturnega spomina so povezane z raziskavami čustev, še posebej v primerih travm in nostalgije, kar sta poudarila tudi zgodovinarka Carrie Hamilton (2012) in antropolog Gananath Obeyesekere (1981). $V$ članku nakažem pomembnost preteklosti pri ustvarjanju novega in na vlogo pripovedi pri ustvarjanju taksnih spominov. Hobsbawm in Ranger (1983) sta nas opomnila, da se izumljanje tradicije in mitologizacija preteklosti pojavljata pogosteje, sploh »kadar se dogajajo številne, dovolj velike in hitre spremembe $v$ družbi, kar lahko vidimo na primeru zgodovine delitev in migracij $v$ Pandžabu. Kaj se od generacije do generacije zavestno ohranjalspominja in kaj se prav tako zavestno pozablja v kulturnem spominu? Kateri sistemi moči so uteleseni v kulturi in plesu? Ali vidimo nostalgično zaobjeto pripoved izgube? In kaj je to, kar najdemo $v$ novih postavitvah diaspore - je to upanje, povezanost, rast in blaginja ali razočaranje in streznitev? $Z$ raziskavo se posebej osredinjam na specifični kraj-Sauthall, vključujem globalni dialog, ki upošteva spreminjanje vzorcev migracij, identitete diaspore in politične odtenke, vidne so šege in navade. Ob tem je Sauthall kompleksno mesto priseljenih skupnosti, od katerih vsaka sabo prinaša svoje spomine in travme o vojni, izgubi, migraciji, naselitvi. Ob napeti rasni zgodovini je bogat in večplasten prostor za srečevanje, sodelovanje in tudi raziskovanje. Ples giddha kot kulturna praksa in sodobna plesna oblika živi naprej in ima pomembno vlogo pri prenosu tradicije in oblikovanju novih praks, pri čemer ponuja različnim generacijam performativno moč za preoblikovanje preteklosti v sedanjost in morda tudi za v prihodnost.

Dr. Ann R. David, University of Roehampton, Department of Dance Roehampton Lane, London, SW15 5PJ, UK, a.david@roehampton.ac.uk. 